Research Article

\title{
In Vivo Antimalarial Activity of 80\% Methanol and Aqueous Bark Extracts of Terminalia brownii Fresen. (Combretaceae) against Plasmodium berghei in Mice
}

\author{
Hana Biruk, ${ }^{1}$ Biruk Sentayehu, ${ }^{2}$ Yonatan Alebachew, ${ }^{2}$ Wondmagegn Tamiru, ${ }^{1}$ \\ Abebe Ejigu $\left(\mathbb{1},{ }^{1}\right.$ and Solomon Assefa $\mathbb{1}^{1}$ \\ ${ }^{1}$ Department of Pharmacology and Clinical Pharmacy, School of Pharmacy, Addis Ababa University, Addis Ababa, Ethiopia \\ ${ }^{2}$ Department of Pharmaceutical Chemistry and Pharmacognosy, School of Pharmacy, Addis Ababa University, \\ Addis Ababa, Ethiopia
}

Correspondence should be addressed to Solomon Assefa; solomon.assefa@aau.edu.et

Received 8 August 2019; Accepted 26 December 2019; Published 24 January 2020

Academic Editor: Andrei Surguchov

Copyright (c) 2020 Hana Biruk et al. This is an open access article distributed under the Creative Commons Attribution License, which permits unrestricted use, distribution, and reproduction in any medium, provided the original work is properly cited.

Background. Despite a substantial scientific progress over the past two decades, malaria continues to be a worldwide burden. Evergrowing resistance towards the currently available antimalarial drugs is a challenge to combat malaria. Medicinal plants are a promising source of new drugs to tackle this problem. Thus, the present study aimed at evaluating the antiplasmodial activity of Terminalia brownii in Plasmodium berghei infected mice. Methods. A 4-day suppressive test was employed to evaluate the antimalarial effect of $80 \%$ methanol and aqueous bark extracts of T. brownii against P. berghei in Swiss albino mice. Results. The in vivo acute toxicity test indicated that both extracts of $T$. brownii did not cause mortality. The 4-day early infection test revealed that the $80 \%$ methanol and aqueous extracts exhibited a significant inhibition of parasitemia $(p<0.001)$ compared to negative control. The maximum level of chemosuppression (60.2\%) was exhibited at $400 \mathrm{mg} / \mathrm{kg}$ dose of $80 \%$ methanol extract. Moreover, the $80 \%$ methanol extract showed a significant $(p<0.001)$ attenuation of anemia associated with infection in a dose-dependent manner. The aqueous extract, on the other hand, exhibited a percent inhibition of $51.1 \%$ at the highest dose ( $400 \mathrm{mg} / \mathrm{kg} / \mathrm{day})$. Conclusion. The present study indicated that hydromethanolic and aqueous bark extracts of $T$. brownii possess a promising antimalarial activity, with higher effect exhibited by the hydromethanolic extract.

\section{Background}

Malaria is a life-threatening disease caused by Plasmodium parasites that are transmitted to human through the bites of infected female Anopheles mosquitoes [1]. Four species of Plasmodium have long been recognized to infect humans in nature. In addition, there is one species, $P$. knowlesi, that naturally infects macaques and has recently been recognized to be a cause of zoonotic malaria in humans [2,3].

According to the World Health Organization's Malaria Report, there were 216 million cases of malaria in 2016. The estimated number of malaria deaths stood at 445,000 in the same year. In 2016, the African region was home to $90 \%$ of malaria cases and $91 \%$ of malaria deaths [1]. Moreover, malaria remains a major killer of children under five years, taking the life of a child every two minutes [1]. It is also a severe disease in Ethiopia, where $75 \%$ of the land is malarious and more than 54 million people are vulnerable $[4,5]$.

Despite a substantial scientific progress over the past two decades, malaria continues to be a worldwide burden [6]. Tremendous effort has been made in the fight against malaria using core disease prevention tools, prompt diagnosis, and treatment with antimalarial medicines. However, the rate at which incidence and mortality of malaria declines has stalled and even reversed in some regions [7]. The resistance towards the currently available antimalarial drugs is seriously challenging the effort to combat malaria. 
Constituting a promising source of new drugs, medicinal plants have been given a priority interest worldwide in the search of safe and effective antiplasmodial agents from plants [8]. Artemisinin derivatives and cinchona alkaloids, such as quinine, are quite exemplary of such assertions. Ethiopia is endowed with abundant medicinal plant resources and traditional medicinal practices [9]. Studies conducted on several traditionally claimed Ethiopian medicinal plants confirmed their antimalarial activities [10-16].

Accordingly, the present study aimed at investigating the in vivo antimalarial activity of the most important plant used in the Ethiopian folkloric medicine for the treatment of malaria, Terminalia brownii [17]. It is a leafy deciduous tree that is usually $4-15 \mathrm{~m}$ high with a rounded, flat topped, spreading crown, and a straight trunk. In a recent study [18], two compounds with a galloyl group, isolated from stem bark extract of the plant, exhibited in vitro antiplasmodial activity against chloroquine-sensitive and chloroquine-resistant strains of $P$. falciparum. But, in vivo antimalarial activity of T. brownii bark was not investigated. The present study, thus, evaluated the in vivo antimalarial activity of $80 \%$ methanol and aqueous extracts of T. brownii barks against $P$. berghei in mice.

\section{Materials and Methods}

\subsection{Collection and Authentication of Plant Material.} Fresh barks of T. brownii Fresen. were collected from Harar town, Eastern Ethiopia, in August 2017. The collected plant material was authenticated by a taxonomist at the National Herbarium, Addis Ababa University, department of biology, where a voucher specimen (HB001) is kept for future reference.

2.2. Experimental Animals. Healthy Swiss albino mice (22-31 g), aged 6-8 weeks (female for toxicity and male for the study), were purchased from the Ethiopian Public Health Institute (EPHI) and kept in the animal house at the School of Pharmacy, Addis Ababa University. Animals were acclimatized for a week just before the experimentation began. Animals were housed in polyethylene cages at room temperature with a $12 \mathrm{~h}$ light-dark cycle and provided with a commercial food and water ad libitum. All procedures and techniques used in this study were in accordance with the Guide for Care and Use of Laboratory Animals [19].

2.3. Rodent Parasite. Chloroquine-sensitive strain of Plasmodium berghei (ANKA) was obtained from EPHI for the in vivo antimalarial assay. The parasites were maintained by serial passage of blood from infected mice to noninfected ones on a weekly basis.

2.4. Extraction. The collected barks of the plant were thoroughly washed with tap water and cleaned with gauze to remove dirt and soil. The manually ground pieces of the bark were dried under shade and pulverized using a mortar and pestle to get a coarse powder before the extraction. The powdered plant material ( $600 \mathrm{~g}$ ) was evenly divided into two portions, for $80 \%$ methanol and aqueous extraction.

The first portion $(300 \mathrm{~g})$ was extracted by cold maceration ( $100 \mathrm{~g}$ of powder in $500 \mathrm{ml}$ of $80 \%$ methanol). The maceration was facilitated using an orbital shaker at $145 \mathrm{rpm}$ for $72 \mathrm{~h}$. The mixture was filtered using a cotton cloth. The filtrates were further passed through Whatman filter paper (No. 1). The residues were remacerated twice, using the same procedure. The methanol in the filtrate of the hydromethanolic extract was removed under reduced pressure by a rotary evaporator (Buchi type TRE121, Switzerland) at $45 \mathrm{rpm}$ and $40^{\circ} \mathrm{C}$ to obtain $80 \%$ methanol extract. The extract was further concentrated to dryness with a lyophilizer (Wagtech Jouan Nordic DK-3450 Allerod, Denmark) at $-50^{\circ} \mathrm{C}$ and under reduced pressure $(200 \mathrm{mBar})$. At the end of the procedure, a $60 \mathrm{~g}$ of dried crude hydromethanolic extract (20\% yield) was harvested.

For aqueous extraction, bark powder $(300 \mathrm{~g})$ were boiled in $1500 \mathrm{ml}$ of distilled water for an hour. The mixture was then filtered using muslin cloth, and filtrates were passed through Whatman filter paper (No. 1). To exhaustively extract the plant part, the procedure was repeated twice. The aqueous extract was frozen in a deep freezer overnight and then freeze-dried with a lyophilizer, using similar conditions stated above. The aqueous extraction yielded $54 \mathrm{~g}$ of dried extract (18\% yield). Both extracts were stored in screw cap vials in a refrigerator at $-4^{\circ} \mathrm{C}$ until use.

2.5. Acute Toxicity Study and Dose Selection. The $80 \%$ methanol and aqueous extracts of T. Brownii were evaluated for their acute toxicity in noninfected female Swiss albino mice, according to OECD Guideline [20]. For each extract, five female mice were used. All mice were fasted for $4 \mathrm{~h}$ before and $2 \mathrm{~h}$ after the administration of the extract. First, a sighting study was performed to determine the starting dose in one mouse. For this, a single dose of $2,000 \mathrm{mg} / \mathrm{kg}$ was administered orally. No death was observed within $24 \mathrm{~h}$. Therefore, an additional four mice were given the same dose of the extract. The animals were observed for overt toxicities such as diarrhea, weight loss, tremor, lethargy, and paralysis periodically for the first four hours during the $24 \mathrm{~h}$ period and then followed for 14 days for any lethality. After acute toxicity test, three dose levels $(100 \mathrm{mg} / \mathrm{kg}, 200 \mathrm{mg} / \mathrm{kg}$, and $400 \mathrm{mg} / \mathrm{kg}$ ) were selected for both extracts [20].

2.6. Parasite Inoculation. To infect the mice, blood from a donor mouse with a parasitemia of about $32-37 \%$ was collected in a Petri dish containing trisodium citrate as an anticoagulant [21]. The blood was then diluted in normal saline so that the final suspension would contain about $1 \times 10^{7}$ infected RBCs in every $0.2 \mathrm{ml}$ suspension. Therefore, each mouse used was infected intraperitoneally with $0.2 \mathrm{ml}$ of infected blood containing about $1 \times 10^{7} \mathrm{P}$. berghei parasitized RBCs.

2.7. Grouping and Dosing of Animals. P. berghei infected mice were randomly divided into eight groups of five mice per group. Group I received $0.2 \mathrm{ml} / \mathrm{kg}$ of distilled water and 
served as a negative control. Group II received $25 \mathrm{mg} / \mathrm{kg}$ dose of chloroquine (CQ), the standard antimalarial drug. Groups III, IV, and V were treated with $80 \%$ methanol extract at a dose of $100 \mathrm{mg} / \mathrm{kg}, 200 \mathrm{mg} / \mathrm{kg}$, and $400 \mathrm{mg} / \mathrm{kg}$, respectively. The remaining groups, groups VI, VII, and VIII, were treated with aqueous extract at $100 \mathrm{mg} / \mathrm{kg}$, $200 \mathrm{mg} / \mathrm{kg}$, and $400 \mathrm{mg} / \mathrm{kg}$ doses, respectively. Each dose was reconstituted by distilled water and administered orally using oral gavage.

2.8. Four-DaySuppressive Test. Evaluation of schizonticidal activity of the plant on early infection was carried out according to the method described by Peter et al. [22]. Treatment, as described in Section 2.7, was started two hours after the mice were inoculated with the parasite on Day 0 . Treatment was then continued daily for four days (from Day 0 to Day 3). On $5^{\text {th }}$ day (D4), blood was collected from the tail of each mouse using clean, nongreasy slides, and thin blood films were made accordingly. The air-dried blood films were then fixed with few drops of methanol and stained with Giemsa at a $\mathrm{pH}$ of 7.2. Parasitemia was examined using a light microscope (Olympus N-120A, Philippines) with X100 objective for determining blood parasite suppression. In addition, each mouse was attended daily for the determination of survival time after treatment. Packed cell volume (PCV) was recorded just before infection and at the end of the experiment.

2.8.1. Parasitemia and Survival Time Measurement. The percentage parasitemia was obtained by counting the number of parasitized red blood cells (PRBC) out of the total erythrocytes in random fields of the microscope. Two stained slides for each mouse were examined using the formula as follows [23]:

$$
\% \text { parasitemia }=\frac{\text { number of } \mathrm{PRBC}}{\text { total number of } \mathrm{RBC}} * 100 \% .
$$

Percent parasitemia suppression was calculated using the following formula [23]:

$$
\text { average } \% \text { suppression of parasitemia }=\frac{\text { parasitemia in negative control }- \text { parasitemia in treatment group }}{\text { parasitemia in negative control }} \times 100
$$

Mice were monitored daily, and the number of days from the time of inoculation up to death was recorded for each mouse in treatment and control groups throughout the follow-up period. The mean survival time (MST) for each group was calculated as follows [14]:

$$
\text { MST }=\frac{\text { sum of survival time of all mice in a group (days) }}{\text { total number of mice in that group }} \text {. }
$$

2.8.2. Packed Cell Volume Measurement. PCV was measured to assess the effect of the two extracts in preventing the hemolytic effect of the Plasmodium parasite. Heparinized capillary tubes were used for the collection of blood from tail of the mice. The tubes were filled to $3 / 4^{\text {th }}$ of their height with blood and sealed with sealing clay at their dry end. The tubes were then placed on a microhematocrit centrifuge (Centurion Scientific, UK) with the sealed end facing the periphery and centrifuged at $11,000 \mathrm{rpm}$ for $5 \mathrm{~min}$. Finally, PCV was determined using a standard hematocrit reader (Hawksley and Sons, England) [22].

$$
\mathrm{PCV}=\frac{\text { volume of erythrocytes in a given volume of blood }}{\text { total blood volume examined }} \times 100 \% \text {. }
$$

\subsubsection{Body Weight and Rectal Temperature Measurement.} Each mouse in a group was weighed using sensitive digital weighing balance, and rectal temperature was measured using digital rectal thermometer. The percentage changes of their mean values that occurred before and after treatment were then calculated.

2.9. Preliminary Phytochemical Analysis. Both extracts were screened for the presence of different phytochemical constituents following standard procedures [24].

2.10. Data Analysis. Results of the study are expressed as mean \pm standard error of mean (SEM). Data were analyzed using SPSS, version 20. Statistical significance was determined by one-way analysis of variance (ANOVA) followed by Tukey post hoc test to compare the levels of parasitemia, survival time, and changes in body weight, PCV, and rectal temperature of the $P$. berghei infected mice between the control and extract-treated groups. $p$ values $<0.05$ were considered as statistically significant.

\section{Results}

3.1. Acute ToxicityStudy. In the in vivo acute toxicity test at a limit dose of $2,000 \mathrm{mg} / \mathrm{kg}$, both extracts of $T$. brownii did not cause mortality and body weight reduction within the first $24 \mathrm{~h}$ as well as in the subsequent 14 days. Moreover, gross physical and behavioral observational study revealed no visible signs of toxicity such as lacrimation, hair erection, and reduction in their motor and feeding activities during the 14 days' follow-up.

3.2. Chemosuppressive Effect of the Plant. The 4-day chemosuppressive study revealed that the $80 \%$ methanol and aqueous extracts of $T$. brownii exhibited a significant 
inhibition of parasitemia $(p<0.001)$ in a dose-dependent manner compared to negative control (Table 1). The level of suppression revealed by $80 \%$ methanol extract at concentrations of $100 \mathrm{mg} / \mathrm{kg} /$ day, $200 \mathrm{mg} / \mathrm{kg} /$ day, and $400 \mathrm{mg} / \mathrm{kg} /$ day in the 4-day suppressive test was $32.7 \%, 47.1 \%$, and $60.2 \%$, respectively. Moreover, the $400 \mathrm{mg} / \mathrm{kg}$ dose of $80 \%$ methanol extract showed a significant inhibition of parasitemia $(p<0.001)$ compared to the $200 \mathrm{mg} / \mathrm{kg}$ and $100 \mathrm{mg} /$ $\mathrm{kg}$ doses of the same extract. The aqueous extract, on the other hand, exhibited a percent inhibition of $25.9 \%, 39.4 \%$, and $51.1 \%$ at dose levels of $100 \mathrm{mg} / \mathrm{kg} / \mathrm{day}, 200 \mathrm{mg} / \mathrm{kg} / \mathrm{day}$, and $400 \mathrm{mg} / \mathrm{kg} /$ day, respectively.

The $80 \%$ methanol and aqueous extracts exhibited a dose-dependent significant $(p<0.001)$ increment of MST compared to negative control. However, their capability of increasing survival time was smaller than that of the standard chloroquine.

The $80 \%$ methanol extract at concentration of $200 \mathrm{mg} /$ $\mathrm{kg} /$ day and $400 \mathrm{mg} / \mathrm{kg} /$ day significantly $(p<0.001)$ prevented loss of body weight associated with infection in a dose-dependent manner compared to control (Table 2). The standard (chloroquine) provided a significant $(p<0.001)$ protection compared to all doses of the $80 \%$ methanol as well as the aqueous extracts.

As indicated in Table 3, the $80 \%$ methanol extract was able to significantly $(p<0.001)$ avert lowering of rectal temperature associated with infection in a dose-dependent manner. The aqueous extract, however, exhibited reduction in rectal temperature associated with infection.

The $80 \%$ methanol extract showed a significant $(p<0.001)$ attenuation of anemia associated with infection in a dose-dependent manner compared to control (Figure 2). Even though the aqueous extract showed a negative percentage change of PCV (Figure 1), it significantly $(p<0.001)$ showed attenuation of anemia associated with infection compared to negative control. Chloroquine exhibited a significant $(p<0.001)$ attenuation of anemia associated with infection compared to all doses of the $80 \%$ methanol as well as the aqueous extract.

3.3. Preliminary Phytochemical Analysis. Phytochemical screening of $80 \%$ methanol and aqueous extracts of $T$. brownii bark revealed the presence of flavonoids, saponins, steroids, tannins, and terpenoids in both extracts (Table 4). However, anthraquinone (o-glycoside) is only present in $80 \%$ methanol extract.

\section{Discussion}

Malaria remains a major public health problem in the world, which is responsible for death of millions of people, particularly in sub-Saharan Africa. Nowadays, malaria control has gradually become more complex due to the spread of drug-resistant parasites [1]. To foil such challenges, it is essential to do extensive researches directed towards the search for new antimalarial drugs. In this regard, medicinal plants have a remarkable track record as a source of safe and effective antimalarial drugs. Artemisinin derivatives could be cited as a prominent example to indicate medicinal plants role in the drug discovery of antimalarial agents. Among several medicinal plants, T. Brownii is one of medicinal plants of antimalarial use in Ethiopian folkloric medicine [25].

The in vivo evaluation of antimalarial compound(s) begins with the use of rodent malaria parasites [26]. Mouse models have demonstrated utility in delineating the mechanisms of several conventional antimalarial agents [21]. P. berghei (ANKA) has been used in studying the activity of antimalarials in mice. This is mainly because of its ability to produce a rodent model of malaria that is similar to human malaria infection [26]. Suppressive test using $P$. berghei infected mice provides a preclinical indication of potential bioactivity of the test sample $[27,28]$.

Oral dosing of the extracts was used in this study, to replicate the ethnomedical method of administration and the likely route during clinical evaluation [25, 29]. Moreover, the acute toxicity result of the present study suggested that the oral medial lethal dose $\left(\mathrm{LD}_{50}\right)$ of both extracts is much greater than $2000 \mathrm{mg} / \mathrm{kg}$ as per OECD guideline No. 425 [20].

In vivo antiplasmodial activity can be classified as moderate, good, and very good if an extract displayed respective percent parasite suppression equal to or greater than $50 \%$ at doses of 500,250 , and $100 \mathrm{mg} / \mathrm{kg}$ body weight per day, respectively [30]. In this study, the level of suppression of $80 \%$ methanol extract $(400 \mathrm{mg} / \mathrm{kg} /$ day) was $60.2 \%$. Based on the above classification, the plant is considered to have exhibited a good antiplasmodial activity. This assertion is evidenced by other in vivo studies that reported antimalarial activity of other species of the same genus such as T. chebula, T. bellerica [31], and T. macroptera [32].

Recently, Mbouna et al. [33] reported the in vitro antiplasmodial activity of $T$. mantaly $\left(\mathrm{IC}_{50}=0.26 \mu \mathrm{g} / \mathrm{mL}\right)$ and T. superba $\left(\mathrm{IC}_{50}=0.57 \mu \mathrm{g} / \mathrm{mL}\right)$ against P. falciparum. Moreover, the parasite suppression exhibited by $80 \%$ methanol extracts is comparable to results of former studies conducted on methanol extract of Artemisia abyssinica [34], Croton macrostachyus [11,35], and Strychnos mitis [36]. The chemosuppression exhibited by aqueous extract, however, is lower than a study conducted on the aqueous extract of $S$. mitis [36].

As is revealed in phytochemical analysis, the presence of flavonoids, saponins, steroids, tannins and terpenoids in both extracts of the study plant could be responsible for its antimalarial activity [18]. The superior antimalarial effect of the methanolic extract could probably be related to the presence of anthraquinone (O-glycoside) in the $80 \%$ methanol extract but not in the aqueous extract [37].

Both extracts of the plant prolonged the mean survival time of the experimental mice indicating that the plant suppressed $P$. berghei and reduced the overall pathologic effect of the parasite on mice. Similar result on mean survival time of mice was reported in studies conducted on $T$. chebula, T. bellerica [31], and T. macroptera [32].

Anemia, body weight loss, and body temperature reduction are the general features of malaria-infected mice [37]. Thus, antimalarial agents are expected to prevent 
TABLE 1: Percent parasitemia and suppression of infected mice treated with $80 \%$ methanol extract and aqueous extracts of Terminalia brownii in the 4-day suppressive test.

\begin{tabular}{|c|c|c|c|c|}
\hline Test substances & Dose (mg/kg/day) & $\%$ parasitemia & \% suppression & Survival days \\
\hline Distilled water & $0.2 \mathrm{ml}$ & $25.5 \pm 0.27$ & 0.00 & $5.8 \pm 0.20$ \\
\hline Methanol extract & $\begin{array}{l}100 \mathrm{mg} \\
200 \mathrm{mg} \\
400 \mathrm{mg}\end{array}$ & $\begin{array}{l}17.2 \pm 0.29 \\
13.5 \pm 0.26 \\
10.2 \pm 0.28 \\
\end{array}$ & $\begin{array}{c}32.7^{\mathrm{a} * \mathrm{c} * \mathrm{~d} *} \\
47.1^{\mathrm{a} * \mathrm{~b} * \mathrm{~d} *} \\
60.2^{\mathrm{a} * \mathrm{~b} * \mathrm{c} * \mathrm{~g} *}\end{array}$ & $\begin{array}{c}8.0 \pm 0.00^{\mathrm{a} *} \\
10.8 \pm 0.20^{\mathrm{a} *} \\
12.8 \pm 0.20^{\mathrm{a} *} \mathrm{e}_{*} \\
\end{array}$ \\
\hline Aqueous extract & $\begin{array}{l}100 \mathrm{mg} \\
200 \mathrm{mg} \\
400 \mathrm{mg}\end{array}$ & $\begin{array}{l}18.9 \pm 0.49 \\
15.5 \pm 0.22 \\
12.5 \pm 0.27 \\
\end{array}$ & $\begin{array}{c}25.9^{\mathrm{a} * \mathrm{f}_{* *} \mathrm{~g}_{*}} \\
39.4^{\mathrm{a} * \mathrm{e}_{*} \mathrm{~g} *} \\
51.1^{\mathrm{a} * \mathrm{~d} * \mathrm{e}_{*} \mathrm{f}_{*}}\end{array}$ & $\begin{array}{l}6.8 \pm 0.20^{\mathrm{a} *} \\
7.0 \pm 0.00^{\mathrm{a} *} \\
7.4 \pm 0.24^{\mathrm{a} *}\end{array}$ \\
\hline Chloroquine & $25 \mathrm{mg}$ & $0.0 \pm 0.00$ & $100.0^{\mathrm{a} * \mathrm{~b} * \mathrm{c} * \mathrm{~d} * \mathrm{e}_{*} \mathrm{f}_{*} \mathrm{~g} *}$ & $28.0 \pm 0.00^{\mathrm{a} * \mathrm{~b} * \mathrm{c} * \mathrm{~d} * \mathrm{e} * \mathrm{f}_{*} \mathrm{~g} *}$ \\
\hline
\end{tabular}

Values are presented as $M \pm \operatorname{SEM} ; n=5 ;{ }^{*}(p<0.001) ; \mathrm{a}=$ compared to negative control; $\mathrm{b}=$ compared to $80 \%$ methanol extract $100 \mathrm{mg} ; \mathrm{c}=$ compared to $80 \%$ methanol extract $200 \mathrm{mg}$; $=$ compared to $80 \%$ methanol extract $400 \mathrm{mg}$; $\mathrm{e}=$ compared to aqueous extract $100 \mathrm{mg}$; $\mathrm{f}=$ compared to aqueous extract $200 \mathrm{mg}$; $\mathrm{g}=$ compared to aqueous extract $400 \mathrm{mg}$.

TABLE 2: Body weight of infected mice treated with $80 \%$ methanol and aqueous extracts of Terminalia brownii in the 4-day suppressive test.

\begin{tabular}{|c|c|c|c|c|}
\hline Test substances & Dose (mg/kg/day) & Pretreatment body weight & Posttreatment body weight & Percentage change $\%$ \\
\hline Distilled water & $0.2 \mathrm{ml}$ & $27.1 \pm 1.17$ & $23.0 \pm 1.08$ & -1.3 \\
\hline Methanol extract & $\begin{array}{l}100 \mathrm{mg} \\
200 \mathrm{mg} \\
400 \mathrm{mg}\end{array}$ & $\begin{array}{l}26.2 \pm 0.67 \\
26.9 \pm 0.53 \\
26.9 \pm 1.00\end{array}$ & $\begin{array}{l}24.2 \pm 0.70 \\
26.9 \pm 0.58 \\
27.1 \pm 1.09\end{array}$ & $\begin{array}{c}-0.4^{\mathrm{a} *} \\
+0.2^{\mathrm{a} * \mathrm{c} *} \\
+0.6^{\mathrm{a} * \mathrm{c} *}\end{array}$ \\
\hline Aqueous extract & $\begin{array}{l}100 \mathrm{mg} \\
200 \mathrm{mg} \\
400 \mathrm{mg}\end{array}$ & $\begin{array}{l}29.1 \pm 0.40 \\
30.5 \pm 0.34 \\
28.9 \pm 0.62\end{array}$ & $\begin{array}{l}26.4 \pm 0.43 \\
28.2 \pm 0.33 \\
26.7 \pm 0.64\end{array}$ & $\begin{array}{l}-0.6^{\mathrm{a} *} \\
-0.3^{\mathrm{a} *} \\
-0.4^{\mathrm{a} *}\end{array}$ \\
\hline Chloroquine & $25 \mathrm{mg}$ & $26.9 \pm 0.80$ & $29.8 \pm 0.80$ & $+2.1^{\mathrm{a} * \mathrm{bc} *}$ \\
\hline
\end{tabular}

Values are presented as $M \pm \mathrm{SEM} ; n=5 ;{ }^{*}(p<0.001) ; \mathrm{a}=$ compared to negative control; $\mathrm{b}=$ compared to $80 \%$ methanol extract; $\mathrm{c}=$ compared to aqueous extract.

TABLE 3: Rectal temperature of infected mice treated with $80 \%$ methanol and aqueous extracts of Terminalia brownii in the 4-day suppressive test.

\begin{tabular}{lcccc}
\hline Test substances & Dose $(\mathrm{mg} / \mathrm{kg} /$ day $)$ & Pretreatment rectal temperature & Posttreatment rectal temperature & Percentage change \% \\
\hline Distilled water & $0.2 \mathrm{ml}$ & $35.9 \pm 0.34$ & $33.3 \pm 0.31$ & -0.4 \\
\hline \multirow{3}{*}{ Methanol extract } & $100 \mathrm{mg}$ & $35.8 \pm 0.28$ & $35.8 \pm 0.22$ & $+0.1^{\mathrm{a} * \mathrm{c} * * \mathrm{~d} *}$ \\
& $200 \mathrm{mg}$ & $36.5 \pm 0.26$ & $36.5 \pm 0.23$ & $+0.3^{\mathrm{a} * \mathrm{c} * * \mathrm{~d} *}$ \\
& $400 \mathrm{mg}$ & $37.0 \pm 0.21$ & $37.5 \pm 0.32$ & $+0.5^{\mathrm{a} * \mathrm{c} * * \mathrm{~d} *}$ \\
\hline \multirow{3}{*}{ Aqueous extract } & $100 \mathrm{mg}$ & $36.4 \pm 0.24$ & $33.3 \pm 0.25$ & -0.5 \\
& $200 \mathrm{mg}$ & $36.9 \pm 0.20$ & $34.3 \pm 0.19$ & -0.3 \\
\hline Chloroquine & $400 \mathrm{mg}$ & $35.9 \pm 0.17$ & $33.4 \pm 0.18$ & -0.4 \\
\hline
\end{tabular}

Values are presented as $M \pm \operatorname{SEM} ; n=5 .{ }^{* *}(p<0.01) ;{ }^{*}(p<0.001) ; \mathrm{a}=$ compared to negative control; $\mathrm{b}=$ compared to $80 \%$ methanol extract; $\mathrm{c}=$ compared to aqueous extract; $\mathrm{d}=$ compared to chloroquine.

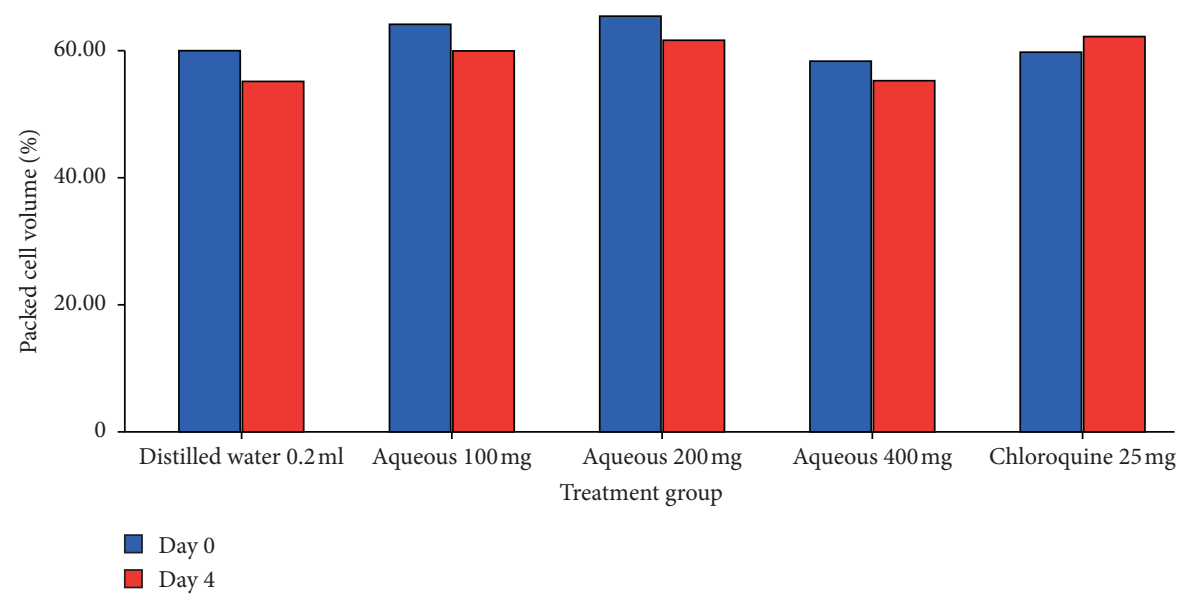

Figure 1: The effect of aqueous extract of T. brownii on packed cell volume of $P$. berghei infected mice on 4-day suppressive test. Values are presented as mean $\pm \mathrm{SEM} ; n=5$; aqueous refers to aqueous extract; numbers refer to doses in $\mathrm{mg} / \mathrm{kg} / \mathrm{day}$. 


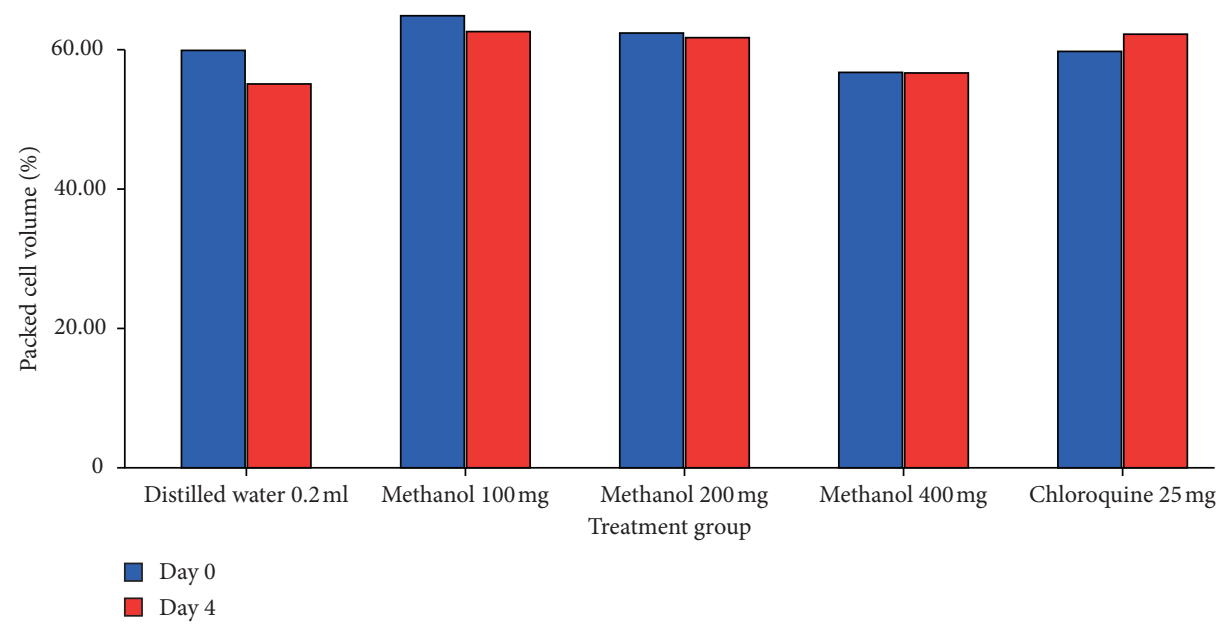

Figure 2: The effect of $80 \%$ methanol extract of T. brownii on packed cell volume of $P$. berghei infected mice on 4-day suppression test. Values are presented as mean $\pm \operatorname{SEM} ; n=5$; methanol refers to methanol extract; numbers refer to doses in $\mathrm{mg} / \mathrm{kg} / \mathrm{day}$.

TABle 4: Preliminary phytochemical screening of $80 \%$ methanol and aqueous extract of Terminalia brownii bark.

\begin{tabular}{lcc}
\hline Phytoconstituents & $80 \%$ methanol extract & Aqueous extract \\
\hline Alkaloids & - & - \\
Anthraquinone (free) & - & - \\
Anthraquinone & + & - \\
(O-glycoside) & + & + \\
Flavonoids & + & - \\
Cardiac glycosides & - & - \\
Coumarin & - & + \\
Saponins & + & + \\
Steroids & + & + \\
Tannins & + & + \\
Terpenoids & + & \\
\hline
\end{tabular}

-, absent; +, present.

pathological features due to a rise in parasitemia. In this study, the $80 \%$ methanol extract exhibited a superior attenuation of anemia compared to the aqueous extract. This likely suggests that the presence of anthraquinone (O-glycoside) may be the major active component that contributes to the antimalarial activity of T. brownii [38].

\section{Conclusion}

The present study indicated a promising in vivo antiplasmodial effect of the $80 \%$ methanol and aqueous extracts of T. brownii. The extracts were also found to be nontoxic at the maximum tested dose of $2000 \mathrm{mg} / \mathrm{kg}$. In addition to upholding the traditional claim of the plant, the results of this study provide a basis for investigating the active compounds of this plant with the purpose of discovering candidate compounds for the development of effective and safe antimalarial drugs.

\section{Data Availability}

The data used to support the findings of this study will be available from the corresponding author on a reasonable request.

\section{Disclosure}

This study was performed as part of a project of the authors at Addis Ababa University, which provided all the laboratory facilities. However, this project did not earn financial support from any part.

\section{Conflicts of Interest}

The authors declare that there are no conflicts of interest regarding the publication of this paper.

\section{Acknowledgments}

The authors are thankful to EPHI for providing experimental animals and parasite.

\section{References}

[1] WHO, Malaria Key Facts, WHO, Geneva, Switzerland, 2018, http://www.who.int/news-room/fact-sheets/detail/malaria.

[2] A. Amirah, F. W. Cheong, J. R. de Silva, J. W. Kent Liew, and Y. L. Lau, "Plasmodium knowlesi malaria: current research perspectives," Infection and Drug Resistance, vol. 11, no. 1, p. 11, 2018.

[3] Center for Disease Control and Prevention (CDC), Malaria Biology: Life Cycle, Center for Disease Control and Prevention (CDC), Atlanta, GA, USA, 2018, https://www.cdc.gov/ malaria/about/biology/index.html.

[4] Y. Legesse, A. Tegegn, T. Belachew, and K. Tushune, "Knowledge, attitude and practice about malaria transmission and its preventive measures among households in urban areas of Assosa zone, western Ethiopia," Ethiopian Journal of Health Development, vol. 21, no. 2, pp. 157-165, 2007.

[5] G. Betemariam and N. Yayeh, "Severe malaria among children in Gambella region, western Ethiopia," Ethiopian Journal of Health Development, vol. 16, no. 1, pp. 61-70, 2002.

[6] T. N. C. Wells, R. H. van Huijsduijnen, and W. C. Van Voorhis, "Malaria medicines: a glass half full?" Nature Reviews Drug Discovery, vol. 14, no. 6, pp. 424-442, 2015. 
[7] "Malaria vaccine implementation programme (MVIP)," 2018, http://www.who.int/immunization/sage/meetings/2018/ april/2_WHO_MalariaMVIPupdate_SAGE_Apr2018.

[8] M. L. Willcox and G. Bodeker, "Traditional herbal medicines for malaria," BMJ, vol. 329, no. 7475, pp. 1156-1159, 2004.

[9] G. Alebie, B. Urga, and A. Worku, "Systematic review on traditional medicinal plants used for the treatment of malaria in Ethiopia: trends and perspectives," Malaria Journal, vol. 16, no. 1, p. 307,2017

[10] E. Mebrahtu, W. Shibeshi, and G. Mirutse, "In vivo antimalarial activity of hydromethanolic leaf extract of Calpurnia aurea (Fabaceae) in mice infected with chloroquine sensitive P. berghei," Intenational Journal of Pharmacy and Pharmacology, vol. 2, no. 9, pp. 131-142, 2013.

[11] L. Bantie, S. Assefa, T. Engidawork, and E. Engdawork, "In vivo antimalarial activity of the crude leaf extract and solvent fractions of Croton macrostachyus Hocsht. (Euphorbiaceae) against Plasmodium berghei in mice," BMC Complementary and Alternative Medicine, vol. 14, no. 1, p. 79, 2014.

[12] D. Yared, M. Yalemtsehay, and D. Asfaw, "In vivo antimalarial activities of fractionated extracts of $A$. africanus in mice infected with P. berghei," PHOL. Arch, vol. 3, pp. 88-94, 2012.

[13] D. Dikasso, E. Makonnen, A. Debella et al., "Anti-malarial activity of Withania somnifera L. dunal extracts in mice," Ethiopian Medical Journal, vol. 44, no. 3, pp. 279-285, 2006.

[14] B. Mengiste, E. Makonnen, and K. Urga, "In vivo antimalarial activity of Dodonaea angustifolia seed extracts against Plasmodium berghei in mice model," Momona Ethiopian Journal of Science, vol. 4, no. 1, p. 47, 2012.

[15] G. Mequanint, "Antimalarial activity of methanolic extract of Phytolacca dodecandra leaves against $P$. berghei infected Swiss albino mice," International Journal of Pharmacology and Clinical Science, vol. 3, no. 3, pp. 39-45, 2014.

[16] D. Nureye, S. Assefa, T. Nedi, and E. Engidawork, "In vivo antimalarial activity of the 80 methanolic root bark extract and solvent fractions of Gardenia ternifolia schumach. \& thonn. (Rubiaceae) against Plasmodium berghei," EvidenceBased Complementary and Alternative Medicine, vol. 2018, Article ID 9217835, 10 pages, 2018.

[17] T. Brownii, "Plant resources of tropical Africa," 2018, http:// uses.plantnet-project.org/en/Terminalia_brownii_(PROTA).

[18] F. Machumi, J. O. Midiwo, M. R. Jacob et al., "Phytochemical, antimicrobial and antiplasmodial investigations of Terminalia brownii," Natural Product Communications, vol. 8, no. 6, 2013.

[19] Institute for Laboratory Animal Research (ILAR), Guide for the Care and Use of Laboratory Animals, National Academy Press, Washington, DC, USA, 1996.

[20] OECD, Guidelines for Testing of Chemicals: Guideline 425: Acute Oral Toxicity, Miracle Works, Paris, France, 2nd edition, 2017.

[21] B. Huang, E. Pearman, and C. Kim, "Mouse models of uncomplicated and fatal malaria," Bio-Protocol, vol. 5, no. 13, Article ID e1514, 2015.

[22] W. Peter, H. Portus, and L. Robinson, "The four-day suppressive in vivo antimalarial test," Annals of Tropical Medicine and Parasitology, vol. 69, pp. 155-171, 1975.

[23] C. D. J. Adumanya, R. M. T. Uwakwe, E. Essien et al., "Antiplasmodial activity of methanol leaf extract of Salacia senegalensis Lam (Dc) in Albino Mice infected with chloroquine-sensitive Plasmodium berghei (NK65)," International Journal of Ethnopharmacololgy, vol. 1, no. 1, pp. 2-6, 2014.

[24] K. Sanjeeb, K. Gaurav, K. Loganathan, V. Kokati, and R. Bhaskara, "Phytochemical composition and in vitro hemolytic activity of Lantana camara L. (Verbenaceae) leaves," Pharmacologyonline, vol. 1, pp. 59-67, 2011.

[25] M. Giday, N. Alelign, T. Teklehaymanot, and A. Animut, "Ethnobotanical survey of antimalarial plants in AwashFentale district of Afar region of Ethiopia and in vivo evaluation of selected ones against Plasmodium berghei," Asian Pacific Journal of Tropical Biomedicine, vol. 8, no. 1, pp. 73-77, 2018.

[26] I. Landau and Y. Boulard, "Life cycle and morphology," in Rodent Malaria, R. Killic-Kendrick and W. Peters, Eds., pp. 53-84, Academic Press, New York, NY, USA, 1978.

[27] R. W. Peter and V. K. Anatoli, The Current Global Malaria Situation. Malaria Parasite Biology, Pathogenesis and Protection, pp. 11-22, ASM Press, Washington, DC, USA, 1998.

[28] D. A. Fidock, P. J. Rosenthal, S. L. Croft, R. Brun, and S. Nwaka, "Antimalarial drug discovery: efficacy models for compound screening," Nature Reviews Drug Discovery, vol. 3, no. 6, pp. 509-520, 2004.

[29] G. Zenebe, M. Zerihun, and Z. Solomon, "An ethnobotanical study of medicinal plants in Asgede Tsimbila district, Northwestern Tigray, Northern Ethiopia," Ethnobotany Research and Applications, vol. 10, pp. 305-320, 2012.

[30] J. K. Obey, M. M. Ngeiywa, K. Paul et al., "Antimalarial activity of Croton macrostachyus stem bark extracts against Plasmodium berghei in vivo," Journal of Pathogens, vol. 2018, Article ID 2393854, 6 pages, 2018.

[31] K. Pinmai, W. Hiriote, N. Soonthornchareonnon, K. Jongsakul, S. Sireeratawong, and S. Tor-Udom, "In vitro and in vivo antiplasmodial activity and cytotoxicity of water extracts of Phyllanthu semblica, Terminalia chebula, and Terminalia bellerica," Journal of Medical Association of Thailand, vol. 93, no. 7, pp. S120-S126, 2010.

[32] M. Haidara, M. Haddad, A. Denou et al., "In vivo validation of anti-malarial activity of crude extracts of Terminalia macroptera, a Malian medicinal plant," Malaria Journal, vol. 17, no. 1, p. 68, 2018.

[33] C. D. J. Mbouna, R. M. T. Kouipou, R. Keumoe et al., "Potent antiplasmodial extracts and fractions from Terminalia mantaly and Terminalia superba," Malaria Journal, vol. 17, no. 1, p. 142, 2018.

[34] M. Adugna, T. Feyera, W. Taddese, and P. Admasu, "In vivo antimalarial activity of crude extract of aerial part of Artemisia abyssinica against Plasmodium berghei in mice," Global Journal of Pharmacology, vol. 8, no. 4, pp. 557-565, 2014.

[35] L. B. Mekonnen, "In vivo antimalarial activity of the crude root and fruit extracts of Croton macrostachyus (Euphorbiaceae) against Plasmodium berghei in mice," American Journal of Medicine, vol. 5, no. 3, pp. 168-173, 2015.

[36] S. Fentahun, E. Makonnen, T. Awas, and M. Giday, "In vivo antimalarial activity of crude extracts and solvent fractions of leaves of Strychnos mitis in Plasmodium berghei infected mice," BMC Complementary and Alternative Medicine, vol. 17, no. 1, p. 13, 2017.

[37] J. Langhorne, S. J. Quin, and L. A. Sanni, "Mouse models of blood-stage malaria infections: immune responses and cytokines involved in protection and pathology," Chemical Immunology and Allergy, vol. 80, pp. 204-228, 2002.

[38] R. Winter, K. A. Cornell, L. L. Johnson, L. M. Isabelle, D. J. Hinrichs, and M. K. Riscoe, "Hydroxy-anthraquinones as antimalarial agents," Bioorganic \& Medicinal Chemistry Letters, vol. 5, no. 17, pp. 1927-1932, 1995. 